\title{
PERBANDINGAN ALGORITMA WINNOWING DENGAN ALGORITMA RABIN KARP UNTUK MENDETEKSI PLAGIARISME PADA KEMIRIPAN TEKS JUDUL SKRIPSI
}

\author{
Fakultas Teknologi Informasi \\ Universitas Islam Kalimantan Muhammad Arsyad Al Banjari Banjari Banjarmasin \\ Nur Alamsyah \\ uniskalam@gmail.com
}

\begin{abstract}
ABSTRAK
Plagiarisme biasanya sering terjadi di dunia Pendidikan, baik itu dalam pengerjaan skripsi atau karya tulis ilmiah, dimana mahasiswa dituntut untuk menyelesaikan skripsinya sebagai syarat kelulusan dan mendapatkan gelar sarjana. Deadline untuk segera menyelesaikan karya tulis ilmiah inilah memicu mereka untuk mencari jalan pintas untuk melakukan copy-paste karya ilmiah atau skripsi orang lain sehingga terjadinya plagiarisme.

Untuk membantu mengurangi tingkat plagiarisme telah banyak dibuat sistem pendeteksi plagiarisme untuk memeriksa tingkat kemiripan teks dokumen. Pada umumnya, sistem pendeteksi plagiarisme dikembangkan untuk data teks seperti essay, artikel, jurnal, penelitian dan dokumen teks yang lebih terstruktur seperti source code bahasa pemrograman.

Untuk mendeteksi plagiarisme atau kemiripan teks dokumen dengan metode fingerprinting dapat dilakukan dengan perbandingan algoritma yang berkaitan pada bidang text mining misal perbandingan pendekatan Algoritma Rabin Karp, Algoritma Manber dan Algoitma Winnowing.

Pendekatan Algoritma Winnowing lebih baik daripada pendekatan algoritma Rabin Karp karena menghasilkan tingkat presentase yang lebih kecil dan waktu proses yang lebih cepat, Berdasarkan hasil Pengujian terhadap perbandingan pendekatan algoritma winnowing dengan algoritma rabin karp dapat dilihat kemungkinan kemiripan teks judul skripsi yang terkecil adalah dengan penggunakan pendekatan algoritma winnowing yaitu pada ujicoba ke 8 dengan nilai n-gram $=9$ dan window $=3$, proses waktu 0.0257 dengan tingkat kemiripan terkecil yaitu $32.6 \%$.
\end{abstract}

Kata Kunci : Algoritma Winnowing, Rabin Karp, fingerprint, n-gram, Hashing, plagiarisme

\section{PENDAHULUAN}

Plagiarisme tampaknya sudah membudaya, mudah terjadi terutama pada jenjang pendidikan S1. Kurangnya kontrol dari pembimbing yang relatif rendah, jumlah pembimbing yang tidak proporsional dengan jumlah mahasiswa dan sumber pustaka yang tidak mutakhir.

Menurut Abdi et al, 2015, plagiarisme adalah penggunaan ulang dari ide atau karya orang lain tanpa menyantumkan sumber aslinya.

Menurut Permendiknas, (Pencegahan dan Penanggulangan Plagiat di Perguruan Tinggi,
No 7, Pasal 1 ayat 1 2010) Plagiat merupakan perbuatan secara sengaja atau tidak sengaja dalam memperoleh atau mencoba memperoleh kredit atau nilai untuk suatu karya ilmiah, dengan mengutip sebagian atau seluruh karya dan/atau karya ilmiah orang lain, tanpa menyatakan sumber secara tepat dan memadai.

Untuk membantu mengurangi tingkat plagiarisme telah banyak dibuat sistem pendeteksi plagiarisme untuk memeriksa tingkat kemiripan teks dokumen. Pada umumnya, sistem pendeteksi plagiarisme dikembangkan untuk data teks seperti essay, artikel, jurnal, penelitian dan dokumen teks 
yang lebih terstruktur seperti source code bahasa pemrograman.

Menurut Telepovska dan Gajdos (2010) aplikasi pendeteksian tersebut dapat menggunakan system local (terisolasi secara offline dan hanya menggunakan database individu) ataupun menggunakan system global (berjalan secara online dan menggunakan server internet sehingga dokumen yang dicari lebih beragam).

\section{Bentuk Plagiarisme}

Menurut Clough (2003) bentuk plagiarism yang bisa terjadi yaitu:

1. Plagiarisme kata per kata, merupakan penyalinan kalimat secara langsung dari sebuah teks dokumen tanpa adanya pengutipan atau perizinan.

2. Plagiarisme paraphrase, merupakan penulisan ulang dengan mengubah kata atau sintaksis, tetapi teks aslinya masih dikenali.

3. Plagiarisme sumber sekunder, merupakan perbuatan mengutip kepada sumber asli yang didapat dari sumber sekunder dengan menghiraukan teks asli dari sumber sebenarnya.

4. Plagiarisme struktur sumber, merupakan penyalinan/ penjiplakan struktur suatu argument dari sebuah sumber.

5. Plagiarisme ide, merupakan penggunaan ulang suatu gagasan / pemikiran asli dari sebuah sumber teks tanpa bergantung bentuk teks sumber.

6. Plagiarisme authorship, merupakan pembubuhan nama sendiri secara langsung pada hasil karya orang lain.

Dari berbagai macam bentuk-bentuk plagiarisme diatas, dapat disimpulkan bahwa tindakan plagiarisme yang sering terjadi dalam dunia Pendidikan lebih cenderung kepada kegiatan menggunakan kembali suatu dokumen teks berupa kata/ kalimat dari suatu sumber yang tidak mengikuti kaidah tata aturan hak cipta, seperti aturan pengutipan (citation) ataupun ketidakjelasan sumber/pengarang asli(bibliography).

\section{Kriteria Plagiarisme}

Hal-hal yang dapat digolongkan sebagai plagiarisme adalah sebagai berikut:

1. Auto Plagiarisme, yakni seseorang yang memuat karyanya sendiri yang sama persis didua atau lebih media.

2. Mengakui karya tulis orang lain sebagai karya tulis sendiri.

3. Mengakui penemuan orang lain sebagai penemuan sendiri.

4. Mengakui gagasan/ide orang lain sebagai gagasan/ide sendiri

5. Meringkas atau mengutip karya orang lain tanpa menyebutkan sumbernya

6. Mengakui karya kelompok sebagai kepunyaan atau hasil sendiri, menyajikan tulisan yang sama dalam rangka yang berbeda tanpa menyebutkan darimana asalnya.

Sedangkan yang bukan termasuk tindak plagiarism adalah:

1. Mengutip karya orang lain (dengan merubah kalimat atau paraphrase) dengan menyebutkan sumbernya.

2. Menggunakan informasi yang merupakan fakta atau hal yang umum digunakan.

3. Menuliskan kembali gagaasan orang lain dengan menyebutkan sumbernya.

\section{Ambang Batas (Threshold) Plagiarisme}

Menurut Sastroasmoro, threshold plagiarisme merupakan nilai ambang batas untuk menentukan apakah dokumen tersebut termasuk kedalam tindak plagiarisme atau tidak, terdapat 3 klasifikasi dalam menentukan ambang batas plagiarism, yaitu:

1. Plagiarisme ringan $:<30 \%$

2. Plagiarisme sedang $:<30 \%-70 \%$

3. Plagiarism berat : $>70 \%$

Namun angka-angka tersebut dapat disesuaikan dan ditentukan sendiri oleh lembaga atau universitas atau fakultas masingmasing. 
Untuk mengatasi praktik plagiarisme, tidak cukup hanya mengingatkan kepada mahasiswa bahwa tindakan tersebut tidak boleh dilakukan, maka harus ada sistem atau metode untuk mendeteksi plagiarisme agar meminimalkan kecurangan dalam praktik plagiarisme.

Metode untuk mendeteksi plagiarisme dapat diklasifikasikan menjadi tiga metode yaitu metode perbandingan teks lengkap, metode dokumen fingerprinting dan metode kesamaan kata kunci.

\section{RUMUSAN MASALAH}

Berdasarkan uraian dari latar belakang, maka dapat dirumuskan masalahnya adalah:

1. Terdapat banyak algoritma dalam mendeteksi plagiarisme, beberapa algoritma yang termasuk dalam metode fingerprinting yaitu algoritma Rabin Karp, algoritma winnowing dan algoritma Mannber untuk deteksi plagiarisme.

2. Membandingkan dua algoritma yaitu algoritma Rabin Karp dengan algoritma Winnowing dalam pendekatan deteksi plagiarisme.

3. Algoritma apa yang paling tepat dan efektif untuk mendeteksi plagiarisme pada teks dokumen khususnya judul skripsi.

\section{TUJUAN PENELITIAN}

Tujuan penelitian ini adalah dengan melakukan perbandingan algoritma Rabin Karp dengan algoritma Winnowing agar dapat diketahui algoritma mana yang paling baik untuk mendeteksi plagiarisme pada dokumen teks, khususnya judul skripsi.

\section{TARGET LUARAN DAN MANFAAT PENELITIAN}

Target Luaran pada penelitian ini adalah setelah nantinya didapatkan mana algoritma terbaik untuk mendeteksi plagiarisme maka dapat diterapkan oleh Ketua Program Studi dalam menentukan tingkat plagiarisme pada judul-judul skripsi yang telah diajukan mahasiswa agar terhindar dari plagiarisme.
Sedangkan manfaat dari penelitian ini adalah untuk memudahkan mendeteksi tingkat plagiarisme pada judul-judul skripsi yang ada difakultas dengan judul skripsi yang diajukan dengan menggunakan algoritma winnowing.

\section{METODE PENELITIAN}

Metode Pendeteksi Plagiarisme di bagi menjadi tiga bagian yaitu metode perbandingan teks lengkap, metode dokumen fingerprinting, dan metode kesamaan kata

kunci. Klasifikasi metode pendeteksi plagiarisme dapat digambarkan sebagai berikut:

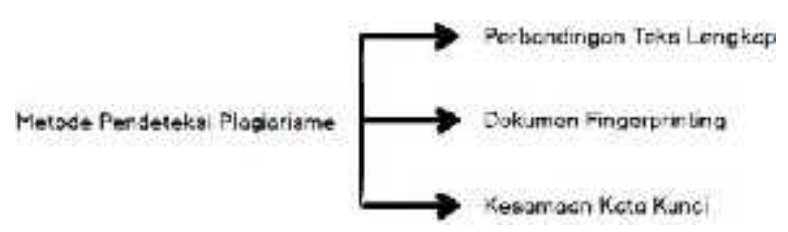

Gambar Klasifikasi Metode Pendeteksi Plagiarisme

Ketiga metode diatas dapat diuraikan sebagai berikut (Stein, 2006) :

\section{Perbandingan Teks Lengkap}

Metode ini di terapkan dengan membandingkan semua isi dokumen. Dapat diterapkan untuk dokumen yang besar. Pendekatan ini membutuhkan waktu yang lama tetapi cukup efektif,

karena kumpulan dokumen yang diperbandingkan adalah dokumen yang di simpan pada penyimpanan lokal. Metode perbandingan teks lengkap tidak dapat diterapkan untuk kumpulan dokumen yang tidak terdapat pada dokumen lokal. Algoritma yang digunakan pada metode ini adalah algoritma brute force, algoritma edit distance, algoritma boyer moore dan algoritma lavenshtein distance

\section{Dokumen Fingerprinting}

Dokumen fingerprinting merupakan metode yang digunakan untuk mendeteksi keakuratan salinan antar dokumen, baik semua teks yang terdapat di dalam dokumen atau hanya sebagian teks saja. Prinsip kerja dari metode dokumen 
fingerprinting ini adalah dengan menggunakan teknik hashing. Teknik hashing adalah sebuah fungsi yang mengkonversi setiap string menjadi bilangan.

\section{Kesamaan Kata Kunci.}

Prinsip dari metode ini adalah mengekstrak kata kunci dari dokumen dan kemudian di bandingkan dengan kata kunci pada dokumen yang lain. Pendekatan yang digunakan pada metode ini adalah teknik dot.

\section{Metode Dokumen Fingerprinting}

Metode fingerprinting adalah metode yang menelusuri karakter satu persatu pada deret karakter. Prinsip kerja dari metode dokumen fingerprinting ini adalah dengan menggunakan teknik hashing. Teknik hashing adalah sebuah fungsi yang mengkonversi setiap string menjadi bilangan. Bilangan-bilangan tersebut menghasilkan nilai-nilai fingerprints sebagai acuan dalam perhitungan kesamaan dokumen. Kelebihan dari metode fingerprinting adalah waktu proses lebih cepat dibandingkan dari metode perbandingan teks lengkap dan metode kesamaan kata kunci. Pengujian similaritas dokumen fingerprinting memiliki tahapan pencarian nilai hashing dari setiap kata, pengambilan nilai fingerprints dan pembobotan persentasi kemiripan.

Beberapa algoritma yang termasuk dalam metode fingerprinting yaitu Algoritma Rabin Karp, Algoritma Winnowing dan Algoritma Rabin Karp . Fokus penelitian ini menggunakan dua algoritma yaitu Algoritma Rabin Karp dan Algoritma Winnowing.

Analisis dilakukan dengan tujuan mendapatkan informasi persentase plagiarisme dari kedua algoritma tersebut dalam penerapannya pada dokumen teks khususnya judul-judul skripsi.

\section{Algoritma Winnowing}

Winnowing adalah algoritma yang digunakan untuk melakukan proses document fingerprinting (Schleimer, Wilkerson, \& Aiken, 2003: 4). Document fingerprinting merupakan metode yang digunakan untuk mendeteksi keakuratan salinan antar dokumen atau hanya sebagian teks saja. Prinsip kerja dari metode document fingerprinting ini adalah dengan menggunakan teknik hashing. Teknik hashing adalah sebuah fungsi yang mengkonversi setiap string menjadi bilangan.

Algoritma winnowing melakukan penghitungan nilai-nilai hash dari setiap $k$ gram, untuk mencari nilai hash selanjutnya digunakan fungsi rolling hash. Kemudian dibentuk window dari nilai-nilai hash tersebut. Dalam setiap window dipilih nilai hash minimum. Jika ada lebih dari satu hash dengan nilai minimum, dipilih nilai hash yang paling kanan. Kemudian semua nilai hash terpilih disimpan untuk dijadikan fingerprint dari suatu dokumen.

Input dari proses document fingerprinting adalah file teks. Kemudian outputnya akan berupa sekumpulan nilai hash yang disebut fingerprint. Fingerprint ini yang akan dijadikan dasar pembanding kesamaan antara teks yang telah dimasukkan.

Syarat dari algoritma deteksi plagiarisme (Schleimer, Wilkerson, \& Aiken, 2003: 2) yaitu;

a. whitespace insensitivity,

yaitu pencocokan teks file seharusnya tidak terpengaruh oleh spasi, jenis huruf kapital, tanda baca dan sebagainya.

b. noise surpression,

yaitu menghindari pencocokan teks file dengan panjang kata yang terlalu kecil atau kurang relevan dan bukan merupakan kata yang umum digunakan.

c. position independence,

yaitu pencocokan teks file seharusnya tidak bergantung pada posisi kata-kata sehingga kata dengan urutan posisi berbeda masih dapat dikenali jika terjadi kesamaan.

Winnowing telah memenuhi syarat-syarat tersebut dengan cara membuang seluruh karakter-karakter yang tidak relevan misal: tanda baca, spasi dan juga karakter lain, 
sehingga nantinya hanya karakter-karakter yang berupa huruf atau angka yang akan diproses lebih lanjut.

Langkah-langkah dalam penerapan Algoritma Winnowing adalah sebagai berikut (Sariyanti Astutik, Andharini Dwi Cahyani, Mochammad Kautsar Sophan, 2014):

\section{Langkah pertama}

\section{Pembuangan Karakter yang Tidak} Relevan.

Yaitu penghapusan tanda baca, spasi dan symbol-simbol seperti =, \#, \%, \&, (, ), -, ,\$, @, !, l,", seperti contoh dibawah ini:

Aplikasi Deteksi Source Code C++

Akan dirubah menjadi

aplikasideteksisourcecodec

\section{Langkah kedua}

Pembentukan Rangkaian n-gram. Yaitu dengan cara membentuk rangkaian karakter sepanjang $n$ dari hasil pembuangan karakter yang tidak relevan, dari teks diatas yang telah dibersihakan dengan ukuran $\mathrm{k}$, ukuran $k=7$ (gram terbaik pada penelitian sebelumnya)

aplikas plikasi likasid ikaside kasidet asidete sidetek ideteks deteksi eteksis teksiso eksisou ksisour sisourc isource sourcec ourceco urcecod rcecode cecodec

\section{Langkah ketiga}

\section{Perhitungan Fungsi Hash untuk} tiap n-gram.

Yaitu melakukan perhitunganperhitungan nilai-nilai hash dari setiap gram, fungsi yang digunakan untuk menghasilkan nilai hash dari rangkaian gram dalam algoritma Winnowing adalah rolling hash.

Rolling Hash adalah suatu cara untuk mentransformasi sebuah string menjadi suatu nilai yang unik dengan panjang tertentu (fixed-length) yang berfungsi sebagai penanda string tersebut. Fungsi untuk menghasilkan nilai ini disebut fungsi hash, sedangkan nilai yang dihasilkan disebut nilai hash.

Fungsi hash $\mathrm{H}_{(\text {c1..ck })}$ didefinisikan sebagai berikut:

$$
\mathbf{H}(c k)=\mathbf{c} 1^{*} \mathbf{b}^{(\mathbf{k}-1)}+\mathbf{c} 2 * \mathbf{b}^{(\mathbf{k}-2)}+\ldots . .+\mathbf{c k} * \mathbf{b}^{(\mathbf{k}-\mathrm{k})}
$$

Keterangan :

$\mathrm{c}=$ nilai ascii karakter

$\mathrm{b}=$ basis (bilangan prima)

$\mathrm{k}=$ banyak karakter

hasil rolling hash dari kalimat diatas adalah

$\begin{array}{lllll}26194 & 27766 & 27060 & 26674 & 26700\end{array}$ 2621027802263942611826866 $\begin{array}{lllll}28098 & 26734 & 27840 & 28486 & 27734\end{array}$ 2878628354284922723425482

\section{Langkah keempat}

\section{Pembentukan Window dari} Nilai Hash.

Pembentukan nilai hash dari window dengan ukuran $w=9$ yaitu : W-1 : \{2619427766 2706026674 $2670026210278022639426118\} \mathrm{W}-$ $2:\{2776627060266742670026210$ $27802263942611826866\}$ W-3 : $\{2706026674267002621027802$ $26394261182686628098\}$ W-4 : \{26674 26700262102780226394 $26118268662809826734\}$ W-5 : $\{2670026210278022639426118$ $26866280982673427840\}$ W-6 : $\{2621027802263942611826866$ $28098267342784028486\}$ W-7 : $\{2780226394261182686628098$ $26734278402848627734\}$ W-8 : \{26394 26118268662809826734 $27840284862773428786\}$ W-9 : \{2611826866280982673427840 $28486277342878628354\} \mathrm{W}-10$ : $\{2686628098267342784028486$ $27734287862835428492\} \mathrm{W}-11$ : $\{2809826734278402848627734$ $28786283542849227234\}$ W-12 : \{2673427840284862773428786 $28354284922723425482\}$ 


\section{Langkah kelima}

\section{Pemilihan Fingerprint dari Setiap} Window

Langkah terakhir yaitu memilih nilai terkecil dari setiap window untuk dijadikan fingerprint, hasil dari nilai fingerprintnya sebagai berikut:

$\begin{array}{lllll}26118 & 26118 & 26118 & 26118 & 26118\end{array}$ 2611826118261182611826734 2673425482

\section{Persamaan Jaccard Coeficient.}

Nilai fingerprint yang dibentuk dari algoritma winnowing digunakan untuk mengukur prosentase kemiripan teks pada persamaan Jaccard Coeficient.

PersamaanJaccardCoefficient

digunakan untuk menghitung kemiripan (similarity) dari kumpulan kata-kata yang telah dihitung nilai hash nya. Berikut ini rumus persamaan Jaccard Coefficient

$$
\text { Similarity }-\frac{\text { Jumlah_fingcrprint_sama }}{\text { Total_seluruh_fingerprint }} \times 100
$$

\section{Algoritma Rabin Karp}

Algoritma Rabin-Karp diciptakan oleh Michael O. Rabin dan Richard. Karp pada tahun 1987 yang menggunakan fungsi hashing untuk menemukan pattern di dalam string teks.

Karakteristik Algoritma Rabin-Karp :

1. Menggunakan sebuah fungsi hashing

2. Fase prepocessing menggunakan kompleksitas waktu $\mathrm{O}(\mathrm{m})$

3. Untuk fase pencarian kompleksitasnya : $\mathrm{O}(\mathrm{mn})$

4. Waktu yang diperlukan $\mathrm{O}(\mathrm{n}+\mathrm{m})$

Algoritma Rabin-Karp adalah algoritma pencocokan string yang menggunakan fungsi hash sebagai pembanding antara string yang dicari $(m)$ dengan substring pada teks $(n)$. Apabila hash value keduanya sama maka akan dilakukan perbandingan sekali lagi terhadap karakter-karakternya. Apabila hasil keduanya tidak sama, maka substring akan bergeser ke kanan. Pergeseran dilakukan sebanyak $(n-m)$ kali. Perhitungan nilai hash yang efisien pada saat pergeseran akan mempengaruhi performa dari algoritma ini

Langkah-langkah dalam algoritma Rabin Karp:

1. Menghilangkan tanda baca dan mengubah ke teks sumber dan kata yang ingin dicari menjadi kata-kata tanpa huruf kapital. Contoh:

Aplikasi Deteksi Source Code C++

Akan dirubah menjadi

aplikasi deteksi source code c

2. Membagi teks ke dalam gram-gram yang ditentukan nilai k-gram nya. Misalkan ukuran $\mathrm{k}=7$ maka hasilnya seperti dibawah ini:

\{aplikas\} \{plikasi\} \{likasi \} \{ikasi d \} \{kasi de $\}$ asi det $\}$ si dete $\}$ i detek $\}$ \{ deteks $\}$ \{deteksi\} \{eteksi $\}$ \{teksi s\} \{eksi so $\}$ ksi sou $\}$ si sour $\}$ i sourc $\}$ \{ source $\}$ \{source $\}$ \{ource c $\}$ urce co\} $\{$ rce cod $\}$ \{ce code $\}$ e code $\}\{$ code $\mathrm{c}\}$

3. Mencari nilai hash dengan fungsi rolling hash dari tiap gram yang terbentuk.

191614241217501169209949739

204832761207007517191955506

22125508019278132274441702

195269355199245837223500051

197988836209673042221276279

19301450377006679223484029

217299753227221413219436636 19226560318569173674404924

4. Mencari nilai hash yang sama antara 2 teks.

$\begin{array}{ccr}191614241 & 217501169 & 209949739 \\ 204832761 & 207007517 & 191955506 \\ 221255080 & 192781322 & 74441702 \\ 195269355 & 199245837 & 223500051 \\ 197988836 & 209673042 & 221276279 \\ 193014503 & 77006679 & 223484029 \\ 217299753 & 227221413 & 219436636 \\ 192265603 & 185691736 & 74404924\end{array}$


5. Menentukan persamaan 2 buah teks dengan persamaan Dice's Similarity

Coefficient.

Untuk menghitung kemiripan dapat digunakan Dice Similarity Coeficients. dengan cara menghitung jumlah K-Gram yang digunakan pada kedua teks nanti yang diuji. Nilai kemiripan tersebut dapat dihitung dengan rumus :

$$
S=\frac{2 C}{A+B}
$$

Dimana:

S = nilai kemiripan

C = jumlah K-Gram yang sama

A serta $\mathbf{B}=$ jumlah K-Gram dari masingmasing string

\section{ANALISIS HASIL DAN PEMBAHASAN}

\section{Analisis Algoritma Winnowing dengan Algoritma Rabin Karp}

Dalam penelitian ini akan dilakukan analisis performansi dari dua buah algoritma yang termasuk dalam metode fingerprinting yaitu Algoritma Winnowing dan Algoritma Rabin Karp yang dapat diterapkan untuk mendeteksi similaritas pada dokumen teks yakni pada judul-judul skripsi.

Analisis performansi dilakukan dengan tujuan mendapatkan informasi dari kedua algoritma yaitu berupa informasi kecepatan, ketepatan, dan jumlah langkah dari Algoritma Winnowing dan Algoritma Rabin Karp dalam penerapannya pada sebuah sistem.

\section{Analisis Input dan Output}

Analisis Input dan Output sistem menjelaskan tentang bagaimana sistem menerima inputan dan menghasilkan output dari proses yang telah dilakukan. Berikut ini merupakan analisis input dan output dari algoritma yang akan dibuat.

\section{Analisis Input dan Output Algoritma Winnowing}

Algoritma Winnowing memiliki input dan output data sebagai berikut.

\section{Analisis Input}

Pada penerapan Algoritma Winnowing dalam sebuah sistem membutuhkan

beberapa inputan meliputi:

1. Dokumen Teks berupa judul-judul skripsi yang berektensi .txt

2. Jumlah Karakter Minimal 100 Huruf

3. Jumlah Gram akan dimulai dengan gram terkecil

4. Jumlah Window akan dimulai dengan window terkecil

\section{Analisis Output}

Output yang dihasilkan dari sistem

berupa:

1. Persentasi Kemiripan dari judul teks yang dibandingkan

2. Informasi Waktu Proses

\section{Analisis Input dan Output Algoritma Rabin Karp}

Algoritma Rabin Karp memiliki input dan output data sebagai berikut:

\section{Analisis Input}

Pada penerapan Algoritma Rabin Karp dalam sebuah sistem membutuhkan beberapa inputan meliputi:

1. Dokumen Teks berektensi .txt

2. Jumlah Karakter Minimal 100 Huruf

3. Jumlah Gram yang dimulai dengan nilai terkecil

\section{Analisis Output}

Output yang dihasilkan dari sistem berupa:

1. Persentasi Kemiripan dari dokumen yang dibandingkan

2. Informasi Waktu Proses

\section{Implementasi Perbandingan Algoritma}

Untuk dapat mengetahui algoritma mana yang terbaik dalam mendeteksi kemiripan teks dokumen khususnya kemiripan teks juduljudul skripsi yang diajukan oleh mahasiswa dengan menerapkan proses algoritma terbaik untuk menghasilkan presentasi kemiripan dan waktu proses. Tujuan utama dari deteksi kemiripan judul adalah untuk menentukan 
presentase kemiripan judul satu dengan judul lainya dengan waktu proses yang lebih cepat.

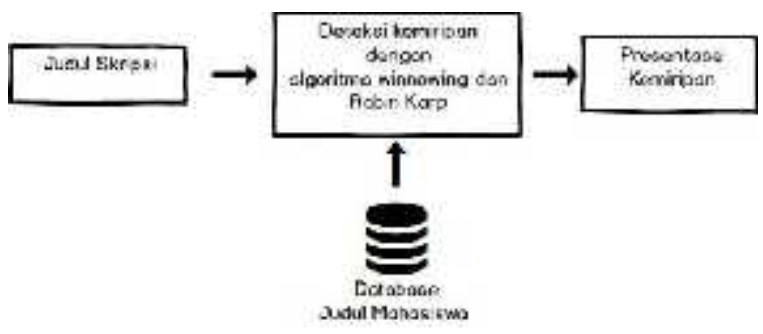

Skema deteksi Kemiripan judul skripsi

Langkah-langkah deteksi kemiripan judul skripsi dapat digambarkan sebagai berikut:

1. Masukan judul skripsi pada masingmasing algoritma yaitu algoritma winnowing dan algoritma Rabin Karp nantinya akan dilihat tingkat presentase dengan judul skripsi yang sudah ada sebelumnya.

2. Memasukan nilai n-gram, untuk memebentuk rangkaian gram pada judul yang dimasukan dan judul yang dibandingkan.

3. MasukannilaiWindow hanya pada

algoritma Winnowing, untuk menentukan pembentukan window dari nilai Hash.

4. Deteksi kemiripan judul skripsi akan diproses dari masing-masing algoritma, dari proses deteksi kemiripan judul tersebut akan menampilkan tingkat presentase dengan judul-judul yang sudah ada sebelumnya.

\section{Implementasi Perbandingan Algoritma}

Tahapan-tahapan untuk mengimplementasikan perbandingan algoritma winnowing dengan algoritma rabin karp untuk mendeteksi presentase plagiarisme pada judul skripsi adalah sebagai berikut;

\section{Ambil 2 buah teks judul skripsi yang akan dibandingkan.}

Teks Judul 1:

\begin{tabular}{c}
\hline "SISTEM PENDUKUNG KEPUTUSAN \\
PENENTUAN KARYAWAN BENGKEL \\
BERPRESTASI MENGGUNAKAN \\
METODE SAW" \\
\hline
\end{tabular}

Teks Judul 2:

"SISTEM PENDUKUNG KEPUTUSAN
BEASISWA PADA MAHASISWA
BERPRESTASI MENGGUNAKAN
METODE AHP"

\section{Pembuangan Karakter yang Tidak Relevan}

Hapus semua huruf yang bukan A-Z, a-z, $0-9$. Kemudian ubah menjadi huruf kecil semua.

Teks Judul 1 akan terbentuk menjadi seperti berikut:

Sistem pendukung keputusan penentuan karyawan bengkel berprestasi menggunakan metodesaw

dan Teks Judul 2 akan terbentuk menjadi seperti berikut:

sistem pendukung keputusan beasiswa pada mahasiswa berprestasi menggunakan me tode ahp

\section{Pembentukan Rangkaian n-gram} pembentukan $n$-gram untuk masingmasing teks judu dan jumlah data pengelompokan $n$-gram ini dimulai dari $2,3,4,5,6,7,8,9,10$ pada masing-masing algoritma.

\section{Pengujian algoritma Winnowing dan} algoritma Rabin Karp Selanjutnya tahap ujicoba dengan membandingkan kedua algoritma sesuai dengan langkah-langkah yang dimiliki oleh algoritma winnowing dan algoritmaRabinKarpdalam menentukan hasil presentase kemiripian teks dokumen khususnya pada judul-judul skipsi. 
Pendekatan Algoritma winnowing berikut tabel serangkaian hasil ujicoba yang telah dilakukan berdasarkan masing-masing algoritma.

ALGORITMA WINNOWING

\begin{tabular}{|c|c|c|c|c|}
\hline uji & $\begin{array}{c}\text { n-gram } \\
\text { (n) }\end{array}$ & $\begin{array}{c}\text { window } \\
\text { (w) }\end{array}$ & $\begin{array}{l}\text { waktu } \\
\text { proses } \\
\text { (second) }\end{array}$ & $\begin{array}{c}\text { kemiripan } \\
\%\end{array}$ \\
\hline \multirow{4}{*}{1} & 2 & 3 & 0.0247 & 73.3 \\
\hline & 2 & 5 & 0.0249 & 71.4 \\
\hline & 2 & 7 & 0.0250 & 66.6 \\
\hline & 2 & 9 & 0.0253 & 66.6 \\
\hline \multirow{4}{*}{2} & 3 & 3 & 0.0281 & 57.5 \\
\hline & 3 & 5 & 0.0303 & 55.1 \\
\hline & 3 & 7 & 0.0260 & 50 \\
\hline & 3 & 9 & 0.0260 & 52.9 \\
\hline \multirow{4}{*}{3} & 4 & 3 & 0.0253 & 48.8 \\
\hline & 4 & 5 & 0.0257 & 50 \\
\hline & 4 & 7 & 0.0270 & 45.5 \\
\hline & 4 & 9 & 0.0261 & 56.2 \\
\hline \multirow{4}{*}{4} & 5 & 3 & 0.0255 & 44.6 \\
\hline & 5 & 5 & 0.0282 & 45.1 \\
\hline & 5 & 7 & 0.0311 & 42.8 \\
\hline & 5 & 9 & 0.0275 & 43.7 \\
\hline \multirow{4}{*}{5} & 6 & 3 & 0.0268 & 40.4 \\
\hline & 6 & 5 & 0.0263 & 43.3 \\
\hline & 6 & 7 & 0.0270 & 42.8 \\
\hline & 6 & 9 & 0.0263 & 43.7 \\
\hline \multirow{4}{*}{6} & 7 & 3 & 0.0252 & 39.5 \\
\hline & 7 & 5 & 0.0294 & 44.8 \\
\hline & 7 & 7 & 0.0260 & 40 \\
\hline & 7 & 9 & 0.0305 & 43.7 \\
\hline \multirow{4}{*}{7} & 8 & 3 & 0.0265 & 36.7 \\
\hline & 8 & 5 & 0.0325 & 40 \\
\hline & 8 & 7 & 0.0289 & 40 \\
\hline & 8 & 9 & 0.0258 & 43.7 \\
\hline \multirow{4}{*}{8} & 9 & 3 & 0.0257 & 32.6 \\
\hline & 9 & 5 & 0.0263 & 33.3 \\
\hline & 9 & 7 & 0.0255 & 33.3 \\
\hline & 9 & 9 & 0.0263 & 35.2 \\
\hline \multirow{4}{*}{9} & 10 & 3 & 0.0263 & 32.6 \\
\hline & 10 & 5 & 0.0263 & 33.3 \\
\hline & 10 & 7 & 0.0274 & 33.3 \\
\hline & 10 & 9 & 0.0308 & 35.2 \\
\hline
\end{tabular}

Berdasarkan dari tabel diatas dapat dilihat bahwa algoritma Winnowing melakukan ujicoba sebanyak 9 kali dengan n-gram memulai dengan $\mathrm{n}=2$ sampai batas akhir $\mathrm{n}$ gram $=10$ kemudian dapat dilihat waktu proses yang berbeda-beda tiap n-gram dan untuk window mulai dari 3, 5, 7, dan 9 window. Dari hasil ujicoba maka dapat ditentukan tiap-tiap n-gram dan window terbaiknya.

Tabel Hasil window dan kemiripan terbaik

ALGORITMA WINNOWING

\begin{tabular}{|c|c|c|c|c|}
\hline $\begin{array}{l}\text { Jumiah } \\
\text { Ujicaba }\end{array}$ & $\begin{array}{c}n=g r a m \\
(n)\end{array}$ & $\begin{array}{c}\text { window } \\
\text { (w) }\end{array}$ & $\begin{array}{c}\text { waktu proses } \\
\text { (second) }\end{array}$ & $\begin{array}{c}\text { kemiripan } \\
\% \\
\end{array}$ \\
\hline 1 & 2 & 7 & 0.0250 & 666.6 \\
\hline 2 & 3 & 7 & 0.0250 & $n$ \\
\hline 3 & 1 & 5 & 0.0257 & in \\
\hline I & 3 & $i$ & 0.0371 & 42.8 \\
\hline$r_{1}$ & $b$ & 3 & 0.0268 & 40.4 \\
\hline 5 & l & 3 & 0.0252 & $3 y .3$ \\
\hline 7 & 8 & 3 & 0.0263 & 36.1 \\
\hline$\pi$ & y) & 3 & $0.025 /$ & 32.0 \\
\hline 9 & 10 & 3 & 0.0263 & 32.6 \\
\hline
\end{tabular}

\section{Pendekatan Algoritma Rabin Karp}

Setelah melakukan ujicoba terhadap nilai n-gram mulai dari 2 sampai dengan 10 maka dapat dilihat hasil pendekatan algoritma Rabin Karp dalam menentukan jumlah n-gram terbaiknya.

\section{ALGORITMA RABIN KARP}

\begin{tabular}{|c|c|c|c|}
\hline $\begin{array}{c}\text { Jumlah } \\
\text { Ujlcoba }\end{array}$ & $\begin{array}{c}\text { n-gram } \\
(\boldsymbol{n})\end{array}$ & $\begin{array}{c}\text { waktu proses } \\
\text { (second) }\end{array}$ & $\begin{array}{c}\text { kemiripan } \\
\%\end{array}$ \\
\hline 1 & 2 & 0.0256 & 84.03 \\
\hline 2 & 3 & 0.0264 & 71.52 \\
\hline 3 & 4 & 0.0245 & 67.90 \\
\hline 4 & 5 & 0.0254 & 64.20 \\
\hline 5 & 6 & 0.0262 & 60.87 \\
\hline 6 & 7 & 0.0253 & 58.75 \\
\hline 7 & 8 & 0.0260 & 56.50 \\
\hline 8 & 9 & 0.0255 & 54.78 \\
\hline 9 & 10 & 0.0280 & 52.90 \\
\hline
\end{tabular}

Berdasarkan dari ujicoba yang telah dilakukan terhadap masing-masing algoritma maka dapat dilihat hasil pengujian seperti tabel dibawah ini: 


\begin{tabular}{|c|c|c|c|c|c|c|c|}
\hline \multirow[b]{2}{*}{ No } & \multicolumn{4}{|c|}{ ALGORITMA WINNOWING } & \multicolumn{3}{|c|}{ ALGORITMA RAUIN KARP } \\
\hline & $\begin{array}{c}\text { n-gam } \\
(n)\end{array}$ & $\begin{array}{l}\text { window } \\
\text { (w) }\end{array}$ & $\begin{array}{c}\text { waktu proses } \\
\text { (secondi) }\end{array}$ & kemiripan & $\begin{array}{c}\text { nosm } \\
\text { (n) }\end{array}$ & $\begin{array}{l}\text { waktu proses } \\
\text { (secend) }\end{array}$ & $\begin{array}{c}\text { kemiripan } \\
\text { s }\end{array}$ \\
\hline 1 & 2 & 7 & 0.0250 & 66.6 & 2 & 0.0266 & 34.01 \\
\hline 2 & 3 & 7 & 00260 & so & 3 & 0.0264 & 71.52 \\
\hline 3 & 4 & 5 & 0.0257 & 50 & 4 & 0.0265 & 67.90 \\
\hline 4 & 5 & 7 & 00311 & 4) 8 & 5 & 0.0254 & 64.20 \\
\hline 5 & 5 & 3 & 0.0268 & 40.4 & 5 & 0.0262 & 50.87 \\
\hline 6 & 7 & 3 & 0.0252 & 39.5 & 7 & 0.0253 & 58.75 \\
\hline 7 & B. & 3 & 0.0265 & 367 & 8 & 0.0260 & 56.60 \\
\hline 8 & 9 & 3 & 0.0257 & 32.6 & 9 & 0.0255 & 54.78 \\
\hline 9 & 10 & 3 & 0.0263 & 12.6 & 10 & 0.0280 & 52.90 \\
\hline
\end{tabular}

Dari hasil perbandingan pendekatan algoritma winnowing dengan algoritma rabin karp dapat dilihat kemungkinan kemiripan teks judul skripsi yang terkecil adalah dengan penggunakan pendekatan algoritma winnowing yaitu pada ujicoba ke 8 dengan nilai $\mathrm{n}$-gram $=9$ dan window $=3$, proses waktu 0.0257 dengan tingkat kemiripan terkecil yaitu $32.6 \%$

\section{PENUTUP}

\section{Kesimpulan}

Berdasarkan hasil pengujian yang telah dilakukan pada masing-masing algoritma yaitu algoritma winnowing dengan algoritma rabin karp terhadap teks judul skripsi, maka dapat ditarik kesimpulan sebagai berikut;

1. Pendekatan Algoritma Winnowing lebih baik daripada pendekatan algoritma Rabin Karp karena menghasilkan tingkat presentase yang lebih kecil dan waktu proses yang lebih cepat.

2. Untuk algoritma winnowing memiliki inputan yaitu dokumen teks berekstensi .txt, jumlah karakter, jumlah Gram dan jumlah Window, sedangkan output yang akan dihasilkan berupa Persentase kemiripan dari teks dokumen yang dibandingkan.

3. Untuk algoritma rabin karp memiliki inputan yaitu dokumen teks berekstensi .txt, jumlah karakter dan jumlah Gram, sedangkan output yang akan dihasilkan berupa Persentase kemiripan dari teks dokumen yang dibandingkan.

4. Terdapat perbedaan mendasar dari kedua algoritma yaitu pada algoritma winnowing memiliki window sedangkan algoritma rabin karp hanya memiliki k-gram
5. Berdasarkan hasil Pengujian terhadap perbandingan pendekatan algoritma winnowing dengan algoritma rabin karp dapat dilihat kemungkinan kemiripan teks judul skripsi yang terkecil adalah dengan penggunakan pendekatan algoritma winnowing yaitu pada ujicoba ke 8 dengan nilai $n$-gram $=9$ dan window $=3$, proses waktu 0.0257 dengan tingkat kemiripan terkecil yaitu $32.6 \%$

\section{Saran}

Berdasarkan dari hasil perbandingan dengan pendekatan algoritma winnowing dengan pendekatan algoritma rabin karp pada deteksi plagiarisme kemiripan teks Judul skripsi masih memiliki kekurangan dan kelemahan.

Oleh Karena itu perlu perbaikan dan perkembangan untuk penelitian selanjutnya dengan saran sebagai beriku:

1. Untuk mendeteksi plagiarisme atau kemiripan teks dokumen dengan metode fingerprinting dapat dilakukan dengan menambah perbandingan algoritma lainnya yang berkaitan pada bidang text mining misal perbandingan Algoritma Rabin Karp,

Algoritma Manber dan Algoitma

Winnowing.

2. Dapat dikembangkan dengan mendeteksi dokumen teks lengkap jadi tidak hanya teks judul skripsi saja.

3. Dapat dibuatkan aplikasi deteksi plagiarisme secara online yang sudah memiliki database judul-judul skripsi mahasiswa yang telah lulus, kemudian mahasiswa yang ingin mengambil judul bisa langsung cek di aplikasi tersebut sebelum mengusulkan judulnya.

\section{DAFTAR PUSTAKA}

Analisis String Matching Pada Judul Skripsi dengan Algoritma Knuth-Morris Pratt(KMP)Agustus 2017ILKOM Jurnal Ilmiah Volume 9 Nomor 2 ISSN 
Cetak 2087-1716 ISSN Online 2548$7779168-172$

Aplikasi Pendeteksi Duplikasi Dokumen Teks

Bahasa Indonesia Menggunakan

Algoritma Winnowing dengan metode

K-gram dan Synonym Recognition.

2011Jurnal Tugas Akhir Jurusan

Teknik Informatika Universitas Muhammadiyah Malang

Christian2013Perancangan Sistem Deteksi Plagiarisme Dokumen Teks Menggunakan Algoritma Damerau Levenshtein DistanceJurnal Mahasiswa PTIIK UB Vol 1

Implementasi Algoritma Winnowing Untuk Deteksi Kemiripan Judul Skripsi Studi Kasus STIMIK BudidarmaJanuari 2017Majalah Ilmiah INTI Volume: XII, Nomor : 1 ISSN : 2339-210X

Implementasi Algoritma Winnowing Untuk Deteksi Kemiripan TextMaret 2015Pelita Informatika Budi Darma, Volume ; IX, Nomor; 1 ISSN 23019425134-138

Implementasi Metode Rabin Karp Untuk Mendeteksi Tingkat Kesamaan Dua Dokumen2013Tugas Akhir Fakultas Sains dan Teknologi Universitas Islam negeri Sultan Syarif Kasim Riau

lmuasih2013Implementasi Algoritma Rabin Karp Untuk Pendeteksian Plagiat Dokumen Teks Menggunakan Konsep Similarity Seminar Nasional Aplikasi Teknologi Informasi (SNATI) ISSN : 1907 - 5022F-23 - F28

NurdinSeptember 2017Sistem Pendeteksian Kemiripan Judul Skripsi Menggunakan Algoritma WinnowingJurnal Nasional Informatika dan Teknologi Jaringan
(InfoTekJar) Vol 2, No 1 e- ISSN : 2540-7600p-ISSN : 2540-7597

Pencocokan Pola Majemuk Dengan Algoritma Rabin Karp2015Makalah IF2211 Startegi Algoritma- Sem.II Halaman 1 6

Penerapan algoritma Boyes Moore Pada Aplikasi Pengajuan Judul Skripsi Berbasis Web2014Seminar Informasi dan Teknologi Ilmiah (INTI)

Plagiarisme, Pelanggaran Hak cipta dan Etika2011JakartaKanisius

2013Rancang Bangun Aplikasi Pendeteksi Penjiplakan Dokumen Menggunakan Algoritma Biword Winnowing Pekanbaru RiauUNIVERSITAS ISLAM NEGERI SULTSN SYARIF KASIM

Sistem Penilaian Esai Otomatis pada ELearning dengan Algoritma WinnowingNovember 2014Jurnal Informatika, Vol 12, No.2 ISSN 1411010547-52 